\title{
Increased rate of potassium fertilizer at the time of heading enhances the quality of direct seeded rice
}

\author{
Anjana J. Atapattu ${ }^{1,2,3}$, B. D. Rohitha Prasantha ${ }^{4^{*}}$ (D, K. S. P. Amaratunga ${ }^{5}$ and Buddhi Marambe ${ }^{6}$
}

\begin{abstract}
Background: Potassium (K) is not easily assimilated into organic matter but helps to improve rice quality. Paddy yield and its quality depend on the correct time of fertilization and harvesting (days after flowering) in the field.

Methods: Changes in the grain quality of (Oryza sativa L.) were studied in a field experiment over two dry seasons using three rates of muriate of potash ( $\mathrm{MOP} ; 60 \% \mathrm{~K}_{2} \mathrm{O}$ ) as $12.5,25$ and $37.5 \mathrm{~kg} / \mathrm{ha}$ applied at the time of heading (7 weeks after planting-WAP). Paddy samples were harvested during 25, 30 (control), 35 and 40 days after 50\% flowering (DAFF). Grain yield and physico-chemical characteristics of grain were studied after harvesting.

Results: The impact of seasons and treatments' interactions was not statistically significant $(P>0.05)$ and, hence, data were averaged over two seasons. Length, breadth, true density and bulk density of rice grains were the highest with $37.5 \mathrm{~kg} \mathrm{MOP} / \mathrm{ha}$ applied at heading and harvested at 30-35 DAFF. Crude protein (6.24\%) and crude fat (2.61\%) contents in grains were the highest when harvested at 40 DAFF and 35-40 DAFF, respectively. Amylose content decreased with increased MOP rates at the time of heading and delayed paddy harvest. The highest average paddy yield (APY; $6.85 \mathrm{t} / \mathrm{ha}$ ), head rice yield (HRY; 65\%) and total rice milling yield (TMY; 67\%) were recorded with $37.5 \mathrm{~kg}$ MOP/ha applied at heading of rice plant and paddy harvested at 35 DAFF. The APY, HRY and TMY were also 13.8, 7.7 and $5.9 \%$ higher, respectively, compared to the control. Applying K fertilizer at a rate $50 \%$ more $(18.75 \mathrm{~kg} \mathrm{~K} / \mathrm{ha})$ than the recommended rate at the time of heading (7 WAP) and harvesting paddy at optimum maturity (35 DAFF), which is 5 days later than the recommendation, increase the yield and grain quality of direct seeded rice. Harvesting later than 35 DAFF resulted in a $10.5 \%$ loss of HRY $(P<0.05)$.
\end{abstract}

Conclusions: The present study showed that $\mathrm{K}$ fertilizer applied at the rate of $37.5 \mathrm{~kg} \mathrm{MOP} / \mathrm{ha}$ at the time of heading $50 \%$ higher than the recommended rate is the best among $\mathrm{K}$ fertilizer treatments to obtain the highest HRY.

Keywords: Grain quality, Potassium, Time of heading, Harvesting, Milling yield, Paddy, Head rice yield

\section{Background}

Paddy (Oryza sativa $\mathrm{L}$ ) is mostly cultivated as a direct seeded crop in Sri Lanka and the annual production is approximately 4.6 million tons resulting in a surplus of rice (de-husked paddy) since 2009 [1]. The annual per capita consumption of rice in Sri Lanka is approximately $116 \mathrm{~kg}$. Expanding cultivation area and adoption of new

\footnotetext{
*Correspondence: bdrp@pdn.ac.lk

${ }^{4}$ Department of Food Science \& Technology, Faculty of Agriculture,

University of Peradeniya, Peradeniya 20400, Sri Lanka

Full list of author information is available at the end of the article
}

high yielding varieties are the major causes for increased productivity. Although increasing the achievable yield from new paddy cultivars is critical for sustainable production, processing and cooking quality of rice has now become important as it determines the acceptability of rice for both export and domestic markets. Changing major agronomic practices such as irrigation, fertilization and harvesting at the correct time are important since they are strongly associated with cooking and processing quality of rice [2]. 
Field crops generally absorb potassium (K) faster than nitrogen $(\mathrm{N})$ or phosphorous $(\mathrm{P})$, where $\mathrm{K}$ also plays an important role in ensuring efficient utilization of $\mathrm{N}$ [2]. Potassium is not easily assimilated into organic matter as in the case of $\mathrm{N}$ and $\mathrm{P}$, but helps in translocation of photosynthetic products and other plant metabolites, thus contributing to improved grain quality [3, 4]. Though $\mathrm{K}$ is not a constituent of any plant structure or compound, $\mathrm{K}$ input plays a role in many important regulatory processes in the plant such as the grain quality of rice [5]. Rice and wheat require large quantities of $\mathrm{K}$, and a continuous supply of $K$ is necessary up to heading stage after completion of the reproduction stage [2, 6]. It was shown that $200-300 \mathrm{~kg} \mathrm{~K}_{2} \mathrm{O} / \mathrm{ha}$ is necessary to obtain $5-10 \mathrm{t} /$ ha of cereal crop yield [7]. Previously studies have also reported that higher $\mathrm{K}$ rates result in a stronger aroma, whiter and glassier appearance and lower softness in basmati rice [8]. Potassium fertilization applied as paniclefertilizer significantly increases the grain yield and quality [9].

Grain yield and its quality depend on the correct judgment on harvesting. Therefore, correct timing of harvesting is important to obtain a higher milling yield with good quality grains [10] fetching higher value for the production in domestic and foreign markets in Europe and Middle East countries. The optimum time for harvesting may be specified by days after flowering of rice panicle [11]. In Sri Lanka, paddy is generally harvested when $80-85 \%$ of the panicles turns into yellow-straw color, which is approximately 30-34 days after completion of flowering [12]. Moisture content at this stage is about $20-22 \%$. Allowing the crop to stand in the field after reaching optimum maturity would reduce the percentage of head rice recovery at milling. Postharvest losses of paddy associated with conventional harvesting and handling (before threshing) operations in the field could vary from 1 to $3 \%$ and 2 to $7 \%$, respectively [13], amounting to approximately $0.12-0.4$ million tons of the total annual production. Hence, determination of the optimum time for harvesting rice varieties is imperative to obtain higher yields and best grain quality. This study was initiated to identify the impact of different rates of $\mathrm{K}$ fertilizer application at the time of heading of rice plant and times of harvesting on the final yield and grain quality of rice.

\section{Methods}

\section{Crop establishment and growth conditions}

Field experiments were carried out during two cultivating seasons (Yala season; March to August) in subsequent years, at the seed farm of the CIC Agri Businesses Private Limited (http://www.cic.lk). The experimental site was located in the agro-ecological region "Low Country Dry Zone (LD)" of Sri Lanka ( $7^{\circ} 30^{\prime} \mathrm{N}$ and $80^{\circ}$ $\left.50^{\prime} \mathrm{E}\right)$. The minimum night temperature of the site varied from 26 to $28{ }^{\circ} \mathrm{C}$ and the maximum day temperature was in the range of $30-33^{\circ} \mathrm{C}$ during the cultivating season of both years. The annual rainfall ranged from $1060 \mathrm{~mm}$ to $1805 \mathrm{~mm}$. The soil was a low humic glay with an average $\mathrm{pH}$ of 5.7 at $0-20 \mathrm{~cm}$ depth. The average soil nutrient composition was $14 \mathrm{~kg} \mathrm{~N}, 709 \mathrm{~kg} \mathrm{P}_{2} \mathrm{O}_{5}, 215 \mathrm{~kg} \mathrm{~K} 2 \mathrm{O}$, $5.4 \mathrm{~kg} \mathrm{Zn}$, and $297 \mathrm{~kg} \mathrm{Mg}$ per hectare, with approximately $1.4 \%$ organic matter. Certified seed paddy (Oryza sativa L) variety CIC 300 obtained from "CIC Agri Businesses" was used for this experiment in both seasons. The paddy variety CIC 300, which matures approximately within 3 months, is with low shattering panicles, red pericarp, and long-grain shape known as basmati type. The variety is produced mainly for the export market requirement.

After land preparation, the experimental area was demarcated by plots at a size of $5 \mathrm{~m} \times 4 \mathrm{~m}$ using bunds of $0.35 \mathrm{~m}$ width and $0.4 \mathrm{~m}$ height. The water outlets of plots were prepared ensuring that the drained water will not enter through an inlet of another plot. Pre-germinated seeds of rice were broadcasted as direct seeded rice at the rate of $100 \mathrm{~kg} / \mathrm{ha}$ while soil moisture was at the field capacity. The total experimental area was about $2000 \mathrm{~m}^{2}$ (0.2 ha). Irrigation, fertilization and other management practices were done according to the recommendations of the Department of Agriculture (DOA), Sri Lanka (http://www.agridept.gov.lk/), except for potassium fertilizer treatments and time of harvesting.

The crop production package for the paddy variety CIC 300 included the fertilizer recommendation made by the DOA for a rice crop grown in the LD with an average yield of $5 \mathrm{t} / \mathrm{ha}$ [14]. The DOA [14] recommended the application of a pre-plant, basal fertilizer mixture comprising urea $(46 \% \mathrm{~N})$ : triple super phosphate (TSP; $46 \%$ $\mathrm{P}_{2} \mathrm{O}_{5}$ ): muriate of potash (MOP; $60 \% \mathrm{~K}_{2} \mathrm{O}$ ) in a ratio of 12.5:62.5:37.5 (kg/ha, w/w/w). As the first and second top dressings, urea was applied 2 and 5 weeks after planting (WAP) at $62.5 \mathrm{~kg} / \mathrm{ha}$ and $100 \mathrm{~kg} / \mathrm{ha}$, respectively.

A mixture of $50 \mathrm{~kg} / \mathrm{ha}$ of urea and $25 \mathrm{~kg} / \mathrm{ha}$ of MOP was applied 7 WAP (time of heading) as recommended by the DOA. The rate of MOP applied 7 WAP was varied in this experiment as follows: as potassium (K) fertilizer supplement at the time of heading was considered the critical time of heading in rice, three levels of MOP applications at the time of heading were evaluated in this study, namely $12.5 \mathrm{~kg} \mathrm{MOP} / \mathrm{ha}(\approx 6.25 \mathrm{~kg} \mathrm{~K} / \mathrm{ha}), 25 \mathrm{~kg} \mathrm{MOP} /$ ha $(\approx 12.5 \mathrm{~kg} \mathrm{~K} / \mathrm{ha})$ and $37.5 \mathrm{~kg} \mathrm{MOP} / \mathrm{ha}(\approx 18.75 \mathrm{~kg} \mathrm{~K} /$ ha). The treatment $25 \mathrm{~kg} \mathrm{MOP} / \mathrm{ha}$ served as the control (recommendation made by the DOA for about 20 years).

The paddy yield was harvested at four different maturity periods (harvesting ages) at 25 days after $50 \%$ flowering (DAFF), 30 DAFF, 35 DAFF and 40 DAFF, at each level of MOP application. In the present study, the rice 
variety reached $50 \%$ flowering stage in about 66 days after planting in both seasons (years). Many rice varieties in Sri Lanka complete flowering after 2-3 days from reaching the 50\% flowering stage. A previous study had identified the correct time for paddy harvest as 30-34 days of post-completion of flowering [12]. Hence, in the present study, 30 DAFF was considered as the control based on the recommendation of the DOA as the optimum time to harvest paddy in Sri Lanka.

\section{Sampling}

Samples were collected using a $2 \mathrm{~m} \times 2 \mathrm{~m}$ quadrant placed at the center of plots and the plants were harvested manually. Threshing was done manually by stripping off the grains from the panicle. All paddy samples were sun dried to have approximately $13 \%$ moisture (wet basis). The samples were packed in perforated polypropylene sacks and kept at $10{ }^{\circ} \mathrm{C}$ until further analysis.

\section{Grain quality and yield measurements}

Paddy samples obtained from each treatment site $(\mathrm{MOP} \times \mathrm{DAFF})$ were weighed to obtain the average paddy yield (APY). The true density of paddy $\left(\mathrm{g} / \mathrm{cm}^{3}\right)$ and bulk density $\left(\mathrm{g} / \mathrm{cm}^{3}\right)$ were determined according to the previous method described by Bhattacharya [15]. The gelatinization temperature (GT) value of the samples was measured by the alkali spreading value method $[16,17]$. The milled rice samples were classified according to the size and shape classification of rice done by the International Rice Research Institute [18]. Fifty paddy grains were randomly picked from each sample and de-hulled with tweezers. The length ( $\mathrm{L}$, major axis) and breadth (B, intermediate axis) of brown rice kernels were measured by a micrometer screw gauge and L/B ratio was calculated [19]. The measurements were repeated 3 times for each sample.

Paddy samples of $150 \mathrm{~g}$ were hulled using a laboratory rubber roll Sheller (XXY155-Yanmar, Japan) and milled with a McGill rice miller (McGill mill No. 2 TX, USA). The broken rice grains were removed manually and also passing the milled rice through a sieve $(2 \mathrm{~mm})$. The milled rice kernels that had at least $2 / 3$ rd of the original kernel length were considered as head rice. The milling percentage of total milled rice yield (TMY) and head rice yield (HRY) recovery was determined as proposed by previous methods $[20,21]$. The milled kernels were ground to flour in a laboratory scale grinder and passed through 80-mesh to obtain uniform particle size. Crude protein $(\mathrm{CP} \%)$ and crude fat $(\mathrm{CF} \%)$ contents were determined using the standard methods of analysis [17]. Apparent amylose content (AC \%) of $100 \mathrm{mg}$ rice flour sample $(<60 \mu \mathrm{m})$ was measured according to the AACC
61-03 method [17] using a UV-visible spectrometer (Jenway- $6305, \mathrm{UK})$ at $620 \mathrm{~nm}$.

\section{Experimental design and statistical analysis}

The experiment was arranged as a two-factor factorial in a randomized complete block design with three replicates. The MOP fertilizer rates, harvesting at different DAFF and their interactions were considered as fixed effects. The analysis of variance (ANOVA) was conducted using the SAS PROC GLM [22]. Initial tests were carried out to identify the effect of seasons and season $x$ treatment interaction on the measured parameters. Treatment means were compared using Duncan's multiple range test (DMRT) at $P=0.05$.

\section{Results}

The impact of cultivating seasons (two) and season $\mathrm{x}$ treatment interactions were not statistically significant $(P>0.05)$ for all the parameters evaluated. Hence, data for each parameter were averaged over two seasons and presented in this section.

\section{Physical quality of rice}

The results of the ANOVA carried out for the physical quality parameters of rice are presented in Table 1. The true density (TD) of paddy harvested did not show any significant interaction $(P>0.05)$ between $\mathrm{K}$ fertilizer rates and harvesting time. However, the TD significantly varied $(P<0.05)$ among the levels of each treatment (Table 1). The TD of rice grain increased and reached the maximum of $1.52 \pm 1.51 \mathrm{~g} / \mathrm{cm}^{3}$ when paddy was harvested between 30 and 35 DAFF (Fig. 1), and decreased to $1.48 \pm 0.005 \mathrm{~g} / \mathrm{cm}^{3}$ at 40 DAFF $(\mathrm{P}<0.05)$. Increase in the level $\mathrm{K}$ fertilization at the time of heading (7 WAP) also increased the TD of rice $(P<0.05)$. The highest TD of $1.50 \pm 0.003 \mathrm{~g} / \mathrm{cm}^{3}$ was observed at $37.5 \mathrm{~kg} \mathrm{MOP} / \mathrm{ha}$ applied at the time of heading. The bulk density (BD) of paddy also increased gradually but significantly $(P<0.05)$ with increased rate of $\mathrm{K}$ fertilizer at the time of heading and with delay of harvesting age. It reached its maximum at 35 DAFF (Table 2). The BD increased by about $8-10 \%$ with the rate of $\mathrm{K}$ fertilizer application higher than $12.5 \mathrm{~kg} / \mathrm{ha}$ at the time of heading.

There was no significant interaction $(P>0.05)$ between the rate of $K$ fertilizer at the time of heading and different harvesting times on grain dimensions. However, each treatment had a significant impact $(P<0.05$; Table 1$)$. The grain length $(\mathrm{L})$ and breadth $(\mathrm{B})$ increased significantly with application MOP fertilizer at rates greater than $25 \mathrm{~kg} / \mathrm{ha}$ at the time of heading and increasing days taken to harvest from 30 DAFF. The highest $\mathrm{L}$ and $\mathrm{B}$ were detected at $37.5 \mathrm{~kg} \mathrm{MOP} / \mathrm{ha}$ applied at the time of heading and harvesting paddy 
Table 1 ANOVA table of potassium fertilizer application at the time of heading and paddy harvest at different days after $\mathbf{5 0 \%}$ flowering (DAFF) on the true density, bulk density, length, breadth, crude protein and crude fat of whole grain

\begin{tabular}{|c|c|c|c|c|c|c|c|}
\hline \multirow[t]{2}{*}{ Source of variation } & \multirow[t]{2}{*}{ df } & \multicolumn{6}{|l|}{$P$ values* } \\
\hline & & True density & Bulk density & Length & Breadth & Crude protein & Crude fat \\
\hline Block & 2 & 0.054 & 0.87 & 0.82 & 0.65 & 0.050 & 0.08 \\
\hline K & 2 & 0.001 & 0.001 & 0.02 & 0.02 & 0.01 & $<0.0001$ \\
\hline DAFF & 3 & $<0.0001$ & $<0.0001$ & $<0.0001$ & $<0.0001$ & 0.04 & $<0.0001$ \\
\hline $\mathrm{K} \times \mathrm{DAFF}$ & 6 & 0.78 & 0.72 & 0.27 & 0.81 & 0.96 & 0.051 \\
\hline
\end{tabular}

$K$ potassium fertilizer as muriate of potash (MOP), DAFF days after $50 \%$ flowering

* Significant effects that require means comparison $P<0.05$
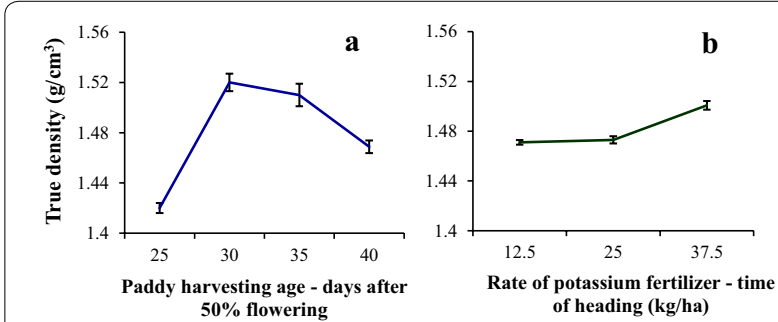

Fig. 1 Average true density of rice grains obtained from two cropping seasons; a when paddy was harvested at different days from $50 \%$ flowering and $\mathbf{b}$ application of different rates of muriate of potash at the time of heading. The vertical bars represent the standard error of the mean (30 DAFF and $25 \mathrm{~kg} \mathrm{MOP} / \mathrm{ha}$ were considered as controls)

approximately at $35 \mathrm{DAFF}$. The $\mathrm{L} / \mathrm{B}$ ratio of the rice grain in all treatments was greater than 4 (Table 2) and the maximum of 4.43 was observed when $\mathrm{K}$ fertilizer was applied at $12.5 \mathrm{~kg} \mathrm{MOP} / \mathrm{ha}$ at the time of heading and paddy was harvested at 25 DAFF. The gelatinization temperature (GT) of the rice variety CIC 300 was $71.7^{\circ} \mathrm{C}$ but showed no significant difference $(P>0.05)$ among all treatments combinations.

\section{Proximate composition}

The crude protein content (CP \%), crude fat content $(\mathrm{CF} \%)$ and amylose content (AC \%) of rice grains did not show a significant interaction $(P>0.05)$ between the two treatments (Tables 1 and 3). The CP content increased significantly $(P<0.05)$ with increasing rate of MOP fertilizer at the time of heading of rice plant and age of paddy at harvesting (Table 4). The highest CP content recorded in this study was $6.24 \%$ with the application of $37.5 \mathrm{~kg}$ $\mathrm{MOP} / \mathrm{ha}$ at the time of heading coupled with harvesting at 40 DAFF. The CF content was 3.3\% higher when $\mathrm{K}$ fertilizer was supplied at the rate of $37.5 \mathrm{~kg} \mathrm{MOP} / \mathrm{ha}$ at the time of heading and $7.8 \%$ higher when paddy was harvested at 35-40 DAFF (Table 4) compared to the respective control (application of $25 \mathrm{~kg} \mathrm{MOP} / \mathrm{ha}$ of at the time of heading and harvesting paddy at $30 \mathrm{DAFF})$. The AC significantly decreased $(P<0.05)$ when the rate of MOP fertilizer applied at the time of heading was increased from 12.5 to $37.5 \mathrm{~kg} / \mathrm{ha}$ and when harvest was delayed from 25 to 40 DAFF (Table 4).

\section{Average paddy yield}

The average paddy yield (APY) was influenced significantly by the interaction effect $(P<0.05)$ between the two treatments (Table 3; Fig. 2). At each $\mathrm{K}$ fertilizer level applied, the APY increased with the age of harvesting and recorded the highest yield of $6.85 \mathrm{Mt} / \mathrm{ha}$ at $35 \mathrm{DAFF}$, which was $13.8 \%$ higher than that recorded in the control plot $(25 \mathrm{~kg} \mathrm{MOP} / \mathrm{ha}$ at the time of heading and harvesting paddy at $30 \mathrm{DAFF}$ ). Delaying paddy harvest beyond 35 DAFF showed a marginal decrease in the APY at all MOP levels applied at the time of heading.

\section{Milled rice yield and head rice yield}

A significant interaction between treatments was observed for milled rice $(P<0.05$; Table 3$)$. Figures 3 and 4 illustrate that delaying paddy harvest from 25 to 35 DAFF has resulted in a gradual increase in TMY and HRY across different rates of MOP applied at the time of heading and a significant decrease $(P<0.05)$ thereafter. At the lowest rate of $\mathrm{K}$ fertilizer applied at the time of heading $(12.5 \mathrm{~kg} / \mathrm{ha})$ and early paddy harvest at $25 \mathrm{DAFF}$, the TMY of rice was the lowest. The highest TMY of $67 \%$ was obtained when MOP was applied at the rate of $37.5 \mathrm{~kg} /$ ha at the time of heading and the paddy was harvested at 35 DAFF, which was 6\% higher than that observed in the control. The highest HRY of $65.3 \%$ was recorded from plots where paddy was harvested at 35 DAFF at the highest MOP level $(37.5 \mathrm{~kg} / \mathrm{ha})$, which was $7.7 \%$ higher than the control. However, irrespective of the rate MOP fertilizer application at the time of heading, the HRY sharply decreased when paddy was harvested late at 40 DAFF. The results revealed that harvesting before 30 and after 
Table 2 Physical grain quality parameters evaluated using different days of paddy harvest from $50 \%$ flowering and potassium fertilizer rates applied at the time of heading

\begin{tabular}{|c|c|c|c|c|c|c|c|}
\hline \multirow[t]{2}{*}{ Grain parameters } & \multicolumn{4}{|c|}{ Harvesting age in days after $50 \%$ flowering (DAFF days) $^{d}$} & \multicolumn{3}{|c|}{$\begin{array}{l}\text { Rate of MOP applied at the time of heading } \\
(\mathrm{kg} / \mathrm{ha})\end{array}$} \\
\hline & 25 & 30 & 35 & 40 & 12.5 & 25 & 37.5 \\
\hline Length $(\mathrm{mm})$ & $6.83 \pm 0.04^{\mathrm{a}}$ & $7.23 \pm 0.05^{b}$ & $7.30 \pm 0.06^{b}$ & $7.25 \pm 0.05^{b}$ & $7.10 \pm 0.02^{\mathrm{a}}$ & $7.10 \pm 0.01^{\mathrm{a}}$ & $7.23 \pm 0.02^{b}$ \\
\hline Breadth $(\mathrm{mm})$ & $1.54 \pm 0.02^{\mathrm{a}}$ & $1.73 \pm 0.04^{b}$ & $1.73 \pm 0.03^{b}$ & $1.74 \pm 0.04^{b}$ & $1.65 \pm 0.01^{\mathrm{a}}$ & $1.70 \pm 0.01^{b}$ & $1.75 \pm 0.01^{c}$ \\
\hline $\mathrm{L} / \mathrm{B}$ & $4.43 \pm 0.03^{b}$ & $4.18 \pm 0.05^{\mathrm{a}}$ & $4.22 \pm 0.05^{\mathrm{a}}$ & $4.16 \pm 0.04^{\mathrm{a}}$ & $4.30 \pm 0.01^{\mathrm{a}}$ & $4.18 \pm 0.02^{b}$ & $4.13 \pm 0.02^{b}$ \\
\hline $\mathrm{BD}\left(\mathrm{g} / \mathrm{cm}^{3}\right)$ & $0.62 \pm 0.01^{\mathrm{a}}$ & $0.68 \pm 0.01^{b}$ & $0.70 \pm 0.02^{b}$ & $0.70 \pm 0.01^{b}$ & $0.64 \pm 0.01^{\mathrm{a}}$ & $0.70 \pm 0.01^{b}$ & $0.70 \pm 0.01^{b}$ \\
\hline
\end{tabular}

$M O P$ muriate of potash (potassium fertilizer; $60 \% \mathrm{~K}_{2} \mathrm{O}$ ), $L / B$ length to breadth ratio of the grain, $B D$ bulk density of the rice grains

Mean $( \pm$ SE) followed by the same superscript within a raw is not significantly different $(P>0.05)$ as measured by the DNMRT

d Data presented as mean $\pm \mathrm{SE}$

Table 3 The ANOVA table of rate of potassium fertilizer and paddy harvest at different days after $50 \%$ flowering on the amylose, average paddy yield, total milled rice and head rice yields of whole grain

\begin{tabular}{|c|c|c|c|c|c|}
\hline \multirow[t]{2}{*}{ Source of variation } & \multirow[t]{2}{*}{ df } & \multicolumn{4}{|l|}{$P$ values* } \\
\hline & & Amylose & Average paddy yield & Total milled rice yield & Head rice yield \\
\hline Block & 2 & 0.96 & 0.48 & 0.85 & 0.20 \\
\hline K & 2 & 0.015 & 0.014 & 0.042 & 0.047 \\
\hline DAFF & 3 & 0.024 & $<0.0001$ & $<0.0001$ & $<0.0001$ \\
\hline $\mathrm{K} \times \mathrm{DAFF}$ & 6 & 0.16 & 0.44 & 0.023 & 0.004 \\
\hline
\end{tabular}

$K$ potassium fertilizer as muriate of potash (MOP), DAFF days after $50 \%$ flowering

*Significant effects that require means comparison $P<0.05$

Table 4 Proximate composition of rice grains when paddy was harvested at different days from $50 \%$ flowering and potassium fertilizer rates applied at the time of heading

\begin{tabular}{|c|c|c|c|c|c|c|c|}
\hline \multirow[t]{2}{*}{ Grain parameters } & \multicolumn{4}{|c|}{ Harvesting age in days after $50 \%$ flowering (DAFF) ${ }^{d}$} & \multicolumn{3}{|c|}{$\begin{array}{l}\text { Rate of MOP applied at the time of heading } \\
(\mathrm{kg} / \mathrm{ha})^{\mathrm{d}}\end{array}$} \\
\hline & 25 & 30 & 35 & 40 & 12.5 & 25 & 37.5 \\
\hline Crude protein (\%) & $5.86 \pm 0.05^{\mathrm{a}}$ & $6.00 \pm 0.05^{\mathrm{ab}}$ & $6.18 \pm 0.03^{b}$ & $6.24 \pm 0.04^{c}$ & $5.87 \pm 0.03^{\mathrm{a}}$ & $6.08 \pm 0.05^{b}$ & $6.24 \pm 0.03^{c}$ \\
\hline Crude fat (\%) & $2.23 \pm 0.05^{\mathrm{a}}$ & $2.42 \pm 0.06^{b}$ & $2.60 \pm 0.06^{c}$ & $2.61 \pm 0.07^{c}$ & $2.43 \pm 0.04^{a}$ & $2.44 \pm 0.06^{\mathrm{a}}$ & $2.52 \pm 0.07^{a}$ \\
\hline Amylose (\%) & $17.84 \pm 0.4^{c}$ & $17.40 \pm 0.3^{b}$ & $16.10 \pm 0.4^{\mathrm{a}}$ & $16.00 \pm 0.3^{a}$ & $17.13 \pm 0.4^{b}$ & $17.6 \pm 0.4^{b}$ & $15.71 \pm 0.2^{\mathrm{a}}$ \\
\hline
\end{tabular}

MOP muriate of potash (potassium fertilizer; $60 \% \mathrm{~K}_{2} \mathrm{O}$ )

Mean $( \pm \mathrm{SE}$ ) followed by the same superscript within a raw is not significantly different $(P>0.05)$ as measured by the DNMRT

d Data present as mean \pm SE

35 DAFF would result in significantly lower $(P<0.05)$ HRY by $6.2 \%$ and $10.5 \%$, respectively.

\section{Discussion}

\section{Grain densities}

The TD and BD are used to assess the level of grain filling with the maturity states of the rice [23]. The TD indicates the exact material density of the product itself. The increase observed in the TD and $\mathrm{BD}$ of rice grains at higher MOP rates applied at 7 WAP with delayed paddy harvest could be due to higher bulking of seeds during grain filling under optimum potassium fertilizer supplement given at the time of heading. Potassium is involved in the transportation of photosynthates from leaves to grain, thereby increasing the dry matter content of the plant and grain. Therefore, changing dry matter or moisture may significantly affect density. Bhattacharya et al. [24] reported that for every $1 \%$ increase in moisture or dry matter, the density of the paddy increased by about $7.5 \mathrm{~kg} / \mathrm{m}^{3}$. Thus, application of $37.5 \mathrm{~kg} \mathrm{MOP} / \mathrm{ha}$ at the time of heading and paddy harvested between 30 and 35 

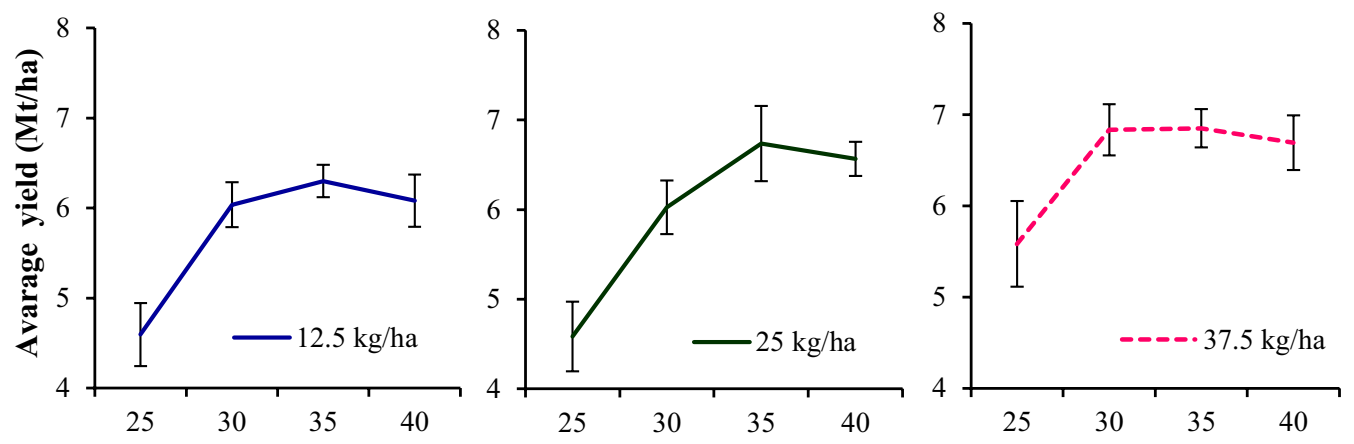

Harvesting age - Days after $50 \%$ flowering

Fig. 2 Average paddy yield harvested at different days from $50 \%$ flowering under three rates of MOP fertilizer ( $\mathrm{kg} / \mathrm{ha}$ ) applied at the time of heading of two cropping seasons. Vertical bars indicate the standard error of the mean (30 DAFF and $25 \mathrm{~kg} \mathrm{MOP} / \mathrm{ha}$ were the controls)
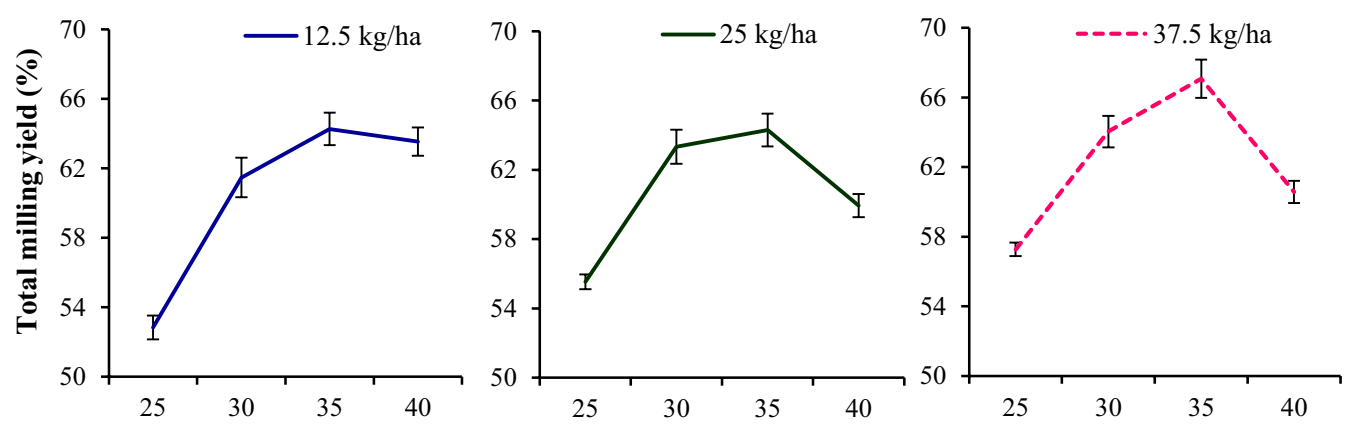

Harvesting age - Days after 50\% flowering

Fig. 3 Total milling yield of rice when paddy was harvested at different days from 50\% flowering at three rates of MOP fertilizer applied (kg/ha) at the time of heading. Vertical bars indicate the standard error of the mean (30 DAFF and $25 \mathrm{~kg} \mathrm{MOP} / \mathrm{ha}$ were the controls)

DAFF could have contributed to the increase of dry matter content by about $6.7 \%$ and $12.6 \%$, respectively.

\section{Grain dimensions}

Quality of rice grain is a complex character composed of many components such as nutritional, appearance, cooking and eating qualities [25]. Thus, the physical properties such as size, shape, uniformity, and general appearance are of utmost importance in determining the final milling quality of rice grains. The head grain dimensions are important when evaluating the rice grain quality as they show clear differences with time due to grain filling [26]. The longer kernel length and other physico-chemical properties were found to be distinctive features of the rice cultivars [27]. The grain $\mathrm{L} / \mathrm{B}$ ratio of the rice grain in all treatments was greater than 3 (Table 2), which could be classified as 'slender' in shape $[19,27]$. Basmati type rice varieties are longer and slender than typical long grain, often with an L/B ratio in the rage of 3.84-5.01 [19].

\section{Gelatinization temperature}

The results of the gelatinized temperature (GT) indicated the grains of the rice variety CIC 300 falls under the category high intermediate as described by [18]. This GT value is common for the majority of basmati type long grain rice varieties found in the world. Previous report showed that [28] application of $\mathrm{K}$ fertilizer did not affect the gelatinization temperature.

\section{Proximate composition}

The crude protein $(\mathrm{CP})$ content of the internationally accepted premium basmati varieties varies between 7 and 9\% [27]. Similar to the data obtained in this study. Another study [28] also reported that application of $\mathrm{K}$ fertilizer increased the grain protein content and gel consistency. According to previous findings, synthesis of 

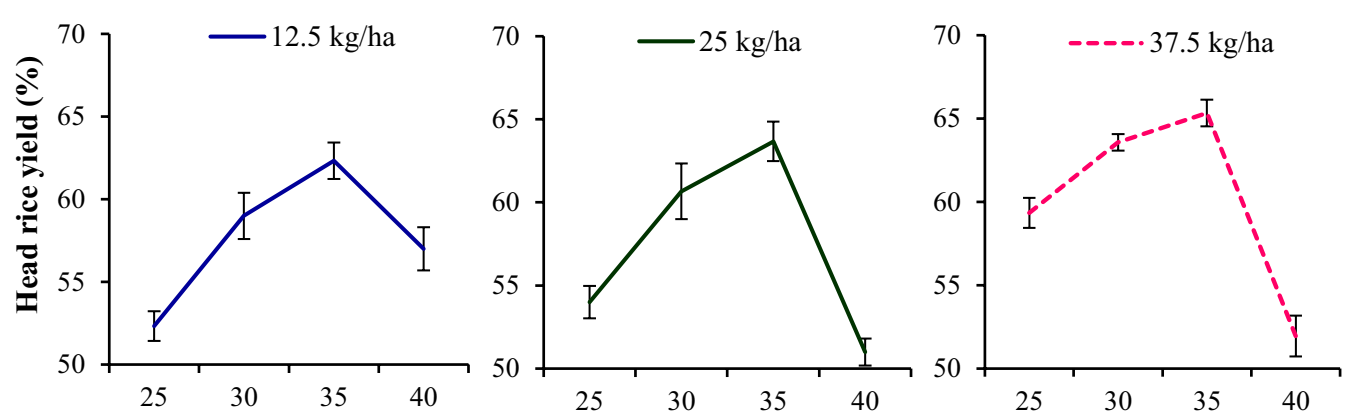

Harvesting age - Days after $50 \%$ flowering

Fig. 4 Average head rice yield when paddy was harvested at different days from 50\% flowering at three rates of MOP fertilizer applied (kg/ha) at the time of heading of two cropping seasons. Vertical bars indicate the standard error of the mean (30 DAFF and $25 \mathrm{~kg} \mathrm{MOP} / \mathrm{ha}$ were the controls)

protein is accelerated in the presence of adequate content of $\mathrm{K}[4,9]$. In the present study, the highest $\mathrm{CP}$ content (6.24\%) recorded in the export rice variety CIC 300 (harvested at 40 DAFF) was marginally lower than the premium quality requirement for the international market. The maximum protein content in rice grain is accumulated 10 days after flowering [23, 29] and it decreases, however, with grain maturity up to 30-35 days after flowering of non-waxy rice [30]. However, low CP content in the rice grains was observed due to the accumulation of higher levels of amylose at harvesting at 25 DAFF across varying $\mathrm{K}$ fertilizer rates at the time of heading of rice plant $[2,9,33]$.

Previous studies have reported that $[27,31]$ the CF content of paddy grains did not significantly differ between japonica and indica varieties but CF content varied between 2.0 and $3.2 \%$ in range. The CF content in the paddy grains in this study became low when paddy was harvested at $25 \mathrm{DAFF}$ and at $\mathrm{K}$ fertilizer rate of $12.5 \mathrm{~kg} \mathrm{MOP} / \mathrm{ha}$ at the time of heading. This could be due to that paddy was harvested at an immature stage when the rice plant did not have enough time to translocate fat into the endosperm of seeds [23]. However, Choudhury and Juliano [32] reported that non-starch lipids in developing paddy grain get accumulated up to 16 days after flowering.

Rice with low amylose content $(\mathrm{AC})$ has been reported to affect the eating and cooking qualities of cooked rice [31]. Previous studies have shown that AC increased in the paddy grain up to 20-21 days after flowering due to the activity of starch synthase and then decreased [29, 33]. The lowest $\mathrm{AC}$ in rice grains after 25 days flowering reported that $\mathrm{AC}$ became constant 30 days after flowering in non-waxy rice [30]. According to Hossain et al. [10], long grain aromatic rice harvested at 30-35 days after flowering was found to be the most suitable for higher head rice out-turn, elongation, volume expansion ratio and $\mathrm{AC}$. It has been shown that the maximum $\mathrm{AC}$ can be obtained by application of $\mathrm{K}$ fertilizer at $180 \mathrm{~kg} \mathrm{~K}_{2} \mathrm{O} /$ ha and $75 \mathrm{~kg} \mathrm{~K} \mathrm{~K}_{2} \mathrm{O} /$ ha with or without $\mathrm{N}$ fertilizer application, respectively [28, 33]. However, the present study found that the increasing rate of $\mathrm{K}$ fertilizer application from 12.5 to $37.5 \mathrm{~kg} \mathrm{MOP} / \mathrm{ha}$ at the time of heading reduced the AC significantly $(P<0.05)$ by about $8.3 \%$. It is also important to note that soil of the experimental site contained an average of $215 \mathrm{~kg}$ of $\mathrm{K} / \mathrm{ha}$. Application of high level $\mathrm{K}$ fertilizer (MOP) at the time of heading together with $\mathrm{N}$ fertilizer at later growth stages $(50 \mathrm{~kg} / \mathrm{ha}$ of urea was added at the time of heading in the present study) or application of $\mathrm{K}$ fertilizer at late growth stage of paddy reduces the enzyme activity of starch synthase [33]. Liu et al. [5] showed that the grain filling regulatory enzyme activity is significantly reduced 20 days after heading and under K-deficient conditions. This could be the reason for decreasing amylose content reported with increasing $\mathrm{K}$ fertilizer rates applied at the time of heading and with delayed paddy harvest. The results highlight the importance of timing of $\mathrm{K}$ fertilizer application to support grain filling of rice plants.

\section{Average paddy yield}

It is well known fact that application of $\mathrm{K}$ fertilizer significantly increases the grain yield by about $47 \%$ with or without organic manure [34, 35]. Potassium deficiency reduces grain size and weight resulting in a direct yield loss if the grain does not respond to K fertilizer applications made after the growth stage of panicle differentiation [6]. According to a nano-material study, application of $\mathrm{K}$ as nano- $\mathrm{K}$ fertilizer at the rate of $20 \mathrm{~kg} \mathrm{~K} / \mathrm{O} / \mathrm{ha}$ showed a significant increase in rice yield and number of seeds per panicle in direct seeded rice [36]. In the present study, the APY may also have decreased when harvested at 40 DAFF due to higher shattering, probably with the lowering of moisture content at the field or due 
to the source limitation to fulfill the sink demand. The same pattern was also observed with respect to TD of the rice grains. According to the previous reported data, an average agronomic response of $6 \mathrm{~kg}$ grain $/ \mathrm{kg}$ of $\mathrm{K}$ for rice and wheat can be obtained by applying $\mathrm{K}$ fertilizer at the rate of $37.5 \mathrm{~kg} / \mathrm{ha}$ [2]. The $\mathrm{K}$ uptake requirements for rice varieties that yield between 4 and $8 \mathrm{t} / \mathrm{h}$ h have ranged from 17 to $30 \mathrm{~kg} \mathrm{~K} / \mathrm{t}$ of grain produced [34].

\section{Total milling rice yield}

The TMY is one of the major parameters that determine the quality of rice, especially in a marketing perspective. Two types of milling yield such as HRY and TMY are considered the most important parameters of determining the quality of rice. A variety should possess a high turnout of HRY and total milled rice. Broken rice is generally valued at only $30-50 \%$ of the whole grain. The accurate measurement of the amounts and classes of broken grains is important and, hence, the standardized procedures are used for official grading. In the present study, the milling yield was low at early harvests (25 DAFF) as the immature grains did not have enough strength to tolerate the mechanical stresses applied during milling [37]. The results also revealed that the best time for harvesting to achieve a higher rice milling yield of direct seeded rice is between 30 and 35 DAFF similar to the previous study [12]. This pattern of variation was also observed in relation to HRY and true density (Figs. 1a and 2).

\section{Head rice yield}

From the consumer's perspective, the HRY is the most important physical quality parameter when determining the grain quality of rice. Harvesting paddy at the optimum crop maturity can give the maximum HRY $[10,38]$ but late harvesting causes significant reduction of the HRY [39]. Similar to the results of this study, another study had also reported that a higher HRY can be obtained when paddy was harvested between 30 and 35 DAFF [10]. Immature grains and low density of rice (Fig. 1a) may be the probable reason for lower HRY recorded during early stages of harvesting at 25 DAFF. This may also lead to higher grain breakage during milling. Delayed harvesting beyond 35 DAFF would also sharply reduce the true density (Fig. 1a) and, therefore, decrease the grain hardness resulting in higher breakages during milling $(>50 \%)$. Although the timeliness of harvesting significantly influences the milling yield, harvesting rice at the optimum crop maturity would result in the maximum HRY [38]. Any delay in harvesting causes reduction of the HRY [39] and extended delay in harvesting could lead to significant losses in HRY.

Wang et al. [9] reported that increased application of $\mathrm{K}$ fertilizer for paddy can significantly improve the percentages of brown rice, milled rice and HRY while reducing the grain chalkiness and enhancing grain protein content. Structural changes such as ordered arrangement of starch granules inside the seed endosperm are also possible with the increasing $K$ fertilizers [23]. Potassium fertilizer is required for maximum yield and it must be applied during the vegetative growth stage [6]. This was clearly reflected by the results of HRY and TMY in the present study, which was significantly reduced with increasing age of harvesting (DAFF) and high rate of $\mathrm{K}$ fertilizer (MOP) application at the time of heading. Application of high doses of $\mathrm{K}$ fertilizer could also increase the percentage of rice bran [40]. The results revealed that application of $50 \%$ higher rate of MOP fertilizer at the time of heading (37.5 $\mathrm{kg} \mathrm{MOP} / \mathrm{ha}$; approx. $18.75 \mathrm{~kg} \mathrm{~K} / \mathrm{ha}$ ) to a low shattering rice variety such as CIC 300 and harvesting paddy 5 days later than the recommended harvesting stage identified by Jayawardena [12] would increase the rice yield (APY, HRY and TMY) and grain quality under direct seeded rice in the dry zone of Sri Lanka.

\section{Conclusion}

The results of the present study showed that $\mathrm{K}$ fertilizer applied at the rate of $37.5 \mathrm{~kg} \mathrm{MOP} / \mathrm{ha}$ at the time of heading, which is $50 \%$ higher than the recommended rate, is the best among $\mathrm{K}$ fertilizer treatments to obtain the highest HRY when rice was harvested from 25 to 35 DAFF. The rice variety CIC 300 belongs to the 3 months age class (mature in 90-93 days after sowing) and, thus, the harvesting paddy between 35 and 40 DAFF could be considered as delayed harvesting. Harvesting before 30 or later than $35 \mathrm{DAFF}$, under different $\mathrm{K}$ fertilizer rates applied at the time of heading of the rice plant, would result in heavy losses during milling.

\section{Abbreviations \\ LD: Low Country Dry Zone; TSP: triple super phosphate; MOP: muriate of potash; WAP: weeks after planting; DAFF: days after 50\% flowering; $\mathrm{K}$ fertilizer: potassium fertilizer; APY: average paddy yield; TD: true density; BD: bulk density; GT: gelatinization temperature; L: grain length; B: breadth; L/B: length to breadth ratio; TMY: total milled rice yield; HRY: head rice yield; $C P$ : crude pro- tein; CF: crude fat; AC: apparent amylose; ANOVA: analysis of variance; DMRT: Duncan's multiple range test; df: degrees of freedom; SE: standard error.}

\section{Authors' contributions}

All authors have equally contributed to the conceptualization and designing of the experiments and preparing the manuscript. AJA carried out the field studies, statistical analysis and interpretation. All authors read and approved the final manuscript.

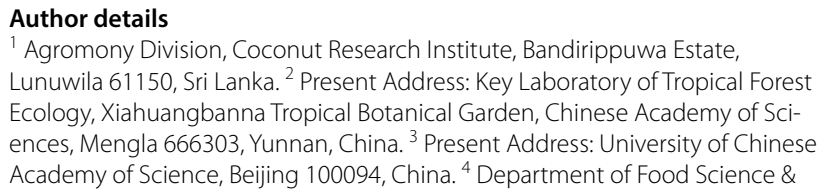


Technology, Faculty of Agriculture, University of Peradeniya, Peradeniya 20400, Sri Lanka. ${ }^{5}$ Department of Agriculture Engineering, Faculty of Agriculture, University of Peradeniya, Peradeniya 20400, Sri Lanka. ${ }^{6}$ Department of Crop Science, Faculty of Agriculture, University of Peradeniya, Peradeniya 20400, Sri Lanka.

\section{Acknowledgements}

The authors wish to thank Messrs. CIC Agri Business (Pvt) Ltd. for providing the seed material other field facilities to complete this study.

\section{Competing interests}

The authors declare that they have no competing interests.

\section{Availability of data and materials}

All available data are shown in figures and tables.

\section{Consent for publication}

All authors give their personal consent for publication.

\section{Ethics approval and consent to participate}

Not applicable.

\section{Funding}

Not applicable.

\section{Publisher's Note}

Springer Nature remains neutral with regard to jurisdictional claims in published maps and institutional affiliations.

Received: 23 August 2018 Accepted: 24 October 2018

Published online: 04 December 2018

\section{References}

1. CBSL Annual Report 2016-economic and social statistics of Sri Lanka. Central Bank of Sri Lanka. http://www.cbsl.gov.lk. Accessed 18 Aug 2018.

2. Singh B, Singh Y, Imas P, Jian-chang Z. Potassium nutrition of the ricewheat cropping system. Adv Agron. 2004;81:203-59.

3. Armengaud P, Breitling R, Amtmann A. The potassium-dependent transcriptome of Arabidopsis reveals a prominent role of jasmonic acid in nutrient signaling. Plant Physiol. 2004;136:2556-76.

4. Armengaud P, Sulpice R, Miller AJ, Stitt M, Amtmann A, Gibon Y. Multilevel analysis of primary metabolism provides new insights into the role of potassium nutrition for glycolysis and nitrogen assimilation in Arabidopsis thaliana roots. Plant Physiol. 2009;150:772-85.

5. Liu $L$, Chang EH, Fan MM, Wang ZQ, Yang JC. Effect of potassium and calcium on root exudates and rain quality during grain filling. Acta Agronomica Sinica. 2011;37:661-9.

6. Fageria NK, Slatonb NA, Baligarc VC. Nutrient management for improving low land rice productivity and sustainability. Adv Agron. 2003;80:63-152.

7. Wild A. Russell's_-soil condition and plant growth. 12th ed. London: English language book society/Longman, UK; 1988.

8. Srivastava P, Srivastava PC, Singh US, Shrivastava M. Effect of integrated and balanced nutrient application on soil fertility, yield and quality of Basmati rice. Arch Agron Soil Sci. 2008;55:265-84.

9. Wong QS, Zhen RH, Ding YH, Ji ZJ, Cao WX, Huang PS. Effects of potassium fertilizer application on plant potassium accumulation and grain quality of japonica rice. Scientia Agricultura Sinica. 2004;37:1444-50 (in Chinese with English abstract).

10. Hossain MF, Bhuiya MSU, Ahmed M, Mian MH. Effect of harvesting time on the milling and physicochemical properties of aromatic rice. Thai J Agric Sci. 2009;42:91-6.

11. Bose SP, Chattopadhyay P. Harvesting and drying of high moisture paddy. Rice Process Eng Center Rep. 1976;2:33-7.

12. Jayawardena SDG. Effect of grain moisture content, time of harvest and method of drying on milling quality of rice. Trop Agric. 1973;129:103-18.

13. Sartaj IZ, Ekanayake S. Postharvest losses. Trop Agric Res. 1991;3:115-32.

14. DOA. Fertilizer recommendation for rice. 2001. http://www.knowledgeb ank.irri.org/sriLanka/fert_reco.html. Accessed 18 Aug 2018.
15. Bhattacharya KR. Gelatinization temperature of rice starch and its determination. In: Proceedings of the Workshop on Chemical Aspects of Rice Brain Quality. Los Baños: IRRI; 1979.

16. Bhattacharya KR, Sawbhagya CM, Indhudharaamy YM. Quality profiles of rice. A tentative scheme for classification. J Food Sci. 1982;47:564-9.

17. AACC. Approved Methods of the American Association of Cereal Chemists, American Association of Cereal Chemists Inc., St. Paul, Minnesota, USA; 2000.

18. Cruz ND, Khush GS. Rice grain quality evaluation procedures. In: Singh RK, Singh US, Khush GS, editors. Aromatic Rices. New Delhi: Oxford and IBH Publishing Co Pvt. Ltd; 2000.

19. Kaur S, Panesar PS, Bera MB. Studies on evaluation of grain quality attributes of some basmati and non-basmati rice cultivars. J Food Qual. 2011:34:435-41.

20. Juliano BO. Rice: chemistry and technology. 2nd ed. St. Paul: American Association of Cereal Chemists; 1985.

21. Archer TR, Siebenmorgen TJ. Milling quality as affected by brown rice temperature. Cereal Chem. 1995;72:304-7.

22. SAS Institute. SAS language and procedures, version 6. 1st ed. Cary: SAS Institute; 1990.

23. Yoshida S. Fundamentals of rice crop science. Manila: International Rice Research Institute; 1981

24. Bhattacharya KR, Sowbhagya CM, Indudhara SYM. Some physical properties of paddy and their interrelation. J Sci Food Agric. 1972;23:171-86.

25. Tan Y-F, Li J-X, Yu S-B, Xing Y-Z, Xu C-G. The three important traits for cooking and eating quality of rice grains are controlled by a single locus in an elite rice hybrid, Shanyou 63. Appl Genet. 1999;99:642-8.

26. Villarreal CP, Juliano BO, Sauphanor B. Grain quality of rice grown in irrigated and upland cultures. Plant Foods Hum Nutr. 1990;40:37-47.

27. Bhattacharjee P, Singhal RS, Kulkarni PR. Basmati rice: a review. Int J Food Sci Technol. 2002:37:1-12.

28. Bahmaniar MA, Ranjbar GA. Response of rice (Oryza sativa L.) cooking quality properties to nitrogen and potassium application. Pak J Biol Sci. 2007;10:1880-4.

29. Baun LC, Palmiano EP, Perez CM, Juliano BO. Enzymes of starch metabolism in the developing rice grain. Plant Physiol. 1970;46:429-34.

30. Tamaki M, Ebata M, Tashiro T, Ishikawa M. Physico-ecological studies on quality formation of rice kernel. II. Changes in quality of rice kernel during grain development. Jpn J Crop Sci. 1989;58:659-63.

31. Zhou Z, Robards K, Helliwell S, Blanchard C. Composition and functional properties of rice. Int J Food Sci Technol. 2002;37:849-68.

32. Choudhury NH, Juliano BO. Lipids in developing and mature rice grain. Photochemistry. 1980;19:1063-9.

33. Ling Z, Ha X-Ch, Wei L, Guo-Tao Y. Effect of nitrogen and potassium on starch content and activities of starch syntase in grains of hybrid rice $B$ You 827. Chin J Rice Sci. 2008;22:551-4.

34. Dobermann A, Cruz PC, Cassman KG. Fertilizer inputs, nutrient balance, and soil nutrient-supplying power in intensive, irrigated rice systems. I. Potassium uptake and K balance. Nutr Cycl Agro Ecosys. 1996;46:1-10.

35. Wickramasinhe WMADB, Wijewardena JDH. Soil fertility management and integrated plant nutrition systems in rice cultivation. In: Abeysiriwardena DS de Z, Dissanayake DM N Nugaliyadde L. Rice Congress 2000. Proceedings rice symposium held in Department of Agriculture, Peradeniya, Sri Lanka, 14-15 December 2000, p. 125-140.

36. Sirisena DN, Dissanayake DMN, Somaweera KATN, Karunaratne V, Kottegoda N. Use of nano-K fertilizer as a source of potassium in rice cultivation. Ann Sri Lanka Dep Agric. 2013;15:257-62.

37. Juliano BO, Villareal CP. Grain quality evaluation of world rice. Manila: International Rice Research Institute; 1993.

38. Bal S, Ojha TP. Determination of biological maturity and effect of harvesting and drying conditions on milling quality of paddy. J Agric Eng Res. 1975;20:353-61.

39. Berrio LE, Cuevas-Perez FE. Cultivar differences in milling yields under delayed harvesting of rice. Crop Sci. 1989;29:1510-2.

40. Bahmaniar MA, Ranjbar GA. Effect of nitrogen potassium fertilizer on rice (Oryza sativa L.) genotype processing characteristics. Pak J Biol Sci. 2007;10:1829-34 